\title{
Rancang Bangun Aplikasi Belajar Membaca dengan Gambar Animasi Berbasis Android
}

\author{
Ghulam Asrofi Buntoro ${ }^{*}$, Indah Puji Astuti², Dwiyono Ariyadi ${ }^{3}$ \\ ${ }^{1,2,3}$ Program Studi Teknik Informatika, Universitas Muhammadiyah Ponorogo \\ Jl. Budi Utomo No.10, Ponorogo, 63471 \\ Email: ghulam@umpo.ac.id, indahpujiastuti@umpo.ac.id, dwiyono,ariyadi@umpo.ac.id
}

\begin{abstract}
Abstrak
Membaca adalah keahlian dasar yang harus dimiliki oleh anak, karena dengan membaca segala ilmu pengetahuan akan cepat masuk dan dipahami oleh manusia. Perkembangan teknologi membuat handphone yang dulu hanya untuk telepon dan kirim pesan sekarang menjadi smartphone yang memiliki lebih banyak fungsi antara lain bisa untuk mengerjakan pekerjaan kantor, video call, game dan masih banyak lagi. Sekarang ini mulai dari anak pra sekolah sudah mahir mengoperasikan smartphone, namun aplikasi yang sering dibuka anak-anak tersebut adalah Game yang tidak ada unsur edukasinya. Salah satu smartphone yang paling banyak dimilik dan digunakan warga Indonesia adalah smartphone berbasis Android. Maka dari itu, Aplikasi yang dibuat dalam penelitian ini adalah aplikasi belajar membaca atau mengenal abjad yang berbasis android dengan gambar animasi. Metode yang digunakan dalam penelitian adalah metode prototype, mulai identifikasi masalah sampai pengujian. Aplikasi telah diuji dengan metode black box dengan hasilnya semua menu-menu atau konten dalam aplikasi berjalan dengan baik. Tujuan dan Harapan dari dibangunnya aplikasi ini adalah menarik minat anak terutama anak usia pra sekolah atau taman kanak-kanak untuk mengenal abjad dengan tampilan aplikasi berupa gambar animasi yang menarik. Aplikasi ini dilengkapi dengan menu bermain untuk melatih kemampuan anak dalam menyambung kata dan mengeja huruf abjad. Hasil pengujian dengan metode black box pada aplikasi yang dibuat menunjukkan bahwa menu-menu sudah sesuai dan berjalan dengan baik sesuai apa yang diharapkan di dokumen perancangan. Dengan adanya aplikasi ini, anak-anak menjadi mempunyai aplikasi belajar abjad Bahasa Indonesia berbasis android yang menarik dan interaktif.
\end{abstract}

Kata kunci : aplikasi, belajar, membaca, game, android

\section{Pendahuluan}

Kementrian Komunikasi dan Informatika Republik Indonesia pada tahun 2015 lewat website resminya menyatakan bahwa Indonesia yang jumlah penduduknya mencapai 250 juta jiwa merupakan pasar yang besar dalam pemasaran Smartphone. Pengguna Smartphone di Indonesia juga akan terus bertambah dari tahun ke tahun[1]. Seperti asumsi Lembaga riset digital marketing emarketer bahwa jumlah pengguna Smartphone di Indonesia akan bertambah dari 67,1 juta pada 2017 menjadi 99,9 juta pada 2021[2]. Survey yang dilakukan oleh Kominfo pada tahun 2017 menunjukkan bahwa lebih dari 50\% masyarakat Indonesia telah memiliki Smartphone[3]. Pernyataan ini diperkuat dengan data statistik yang dikeluarkan oleh BPS tahun 2018[4], bahwa pengguna telepon selular di Indonesia terus mengalami peningkatan dimana pada tahun 2018 jumlahnya mencapai $62,41 \%$.

Dari data di atas dapat dikatakan bahwa mayoritas masyarakat Indonesia sudah menggunakan Smartphone. Mulai dari anak-anak, remaja, pekerja maupun ibu rumah tangga. Sudah banyak orang tua yang memfasilitasi anak-anak mereka dengan Smartphone, dengan harapan Smartphone dapat digunakan sebagai media pendukung pembelajaran[5][6].

Data yang ditunjukkan oleh The Asian Parent Insights[7] dimana harapan orang tua dalam penggunaan Smartphone oleh anak masih belum sesuai harapan. Data menunjukkan bahwa harapan orang tua, anak akan mengakses aplikasi pendidikan sebanyak $81 \%$, akan tetapi dalam kenyataannya penggunaan oleh anak di kriteria ini baru mencapai angka 57\% saja. Game adalah yang paling diminati anak ketika menggunakan Smartphone, dimana angkanya mencapai $72 \%$. Hal inilah yang menjadi kehawatiran orang tua akan penggunaan Smartphone pada anak terutama usia pra sekolah.

Dari latar belakang di atas, penelitian ini bertujuan untuk mengembangkan aplikasi belajar membaca berbasis android dengan menambahkan unsur animasi di dalamnya. Harapan dari dibangunnya aplikasi ini adalah supaya anak pra sekolah akan lebih tertarik untuk belajar membaca dan dapat memanfaatkan Smartphone tidak hanya untuk bermain game tetapi juga untuk media belajar. 


\section{Tinjauan Pustaka}

Zaini dan Sunarto menyatakan pada penelitiannya[8] bahwa dari pengguna Smartphone di Indonesia yang mencapai 177,9 juta jiwa, penyumbang terbesar diantaranya adalah dari kategori anak-anak dan remaja. Hasil penelitian yang dilakukan oleh Heni dan Mujahid menunjukan bahwa dari sample sebanyak 33 anak, 24 diantaranya $(72.7 \%)$ atau lebih dari setengahnya anak usia pra sekolah sebagai pengguna smartphone dengan frekuensi sering[9].

Pada penelitian yang dilakukan oleh Febriati dan Fauziah tentang intensitas penggunaan gadget pada anak usia pra sekolah dalam sehari anak menggunakan Smartphone sekitar 2 jam untuk game, youtube, program interaktif, kartun atau yang lainnya[10]. Namun dari data tersebut dengan kriteria seberapa sering anak mau membaca kata-kata dari layar gadget menunjukkan hasil hampir semuanya responden tidak pernah. Dapat dikatakan bahwa ketertarikan anak untuk menggunakan Smartphone sebagai media untuk belajar atau membaca masih sangat rendah.

Muludi dkk telah membangun aplikasi Iqro' berbasis Android dengan tujuan untuk media pembelajaran alternatif mempelajari iqro' disamping menggunakan buku Iqro'[11]. Aplikasi dibuat interaktif sehingga mempermudah siswa dalam mempelajarinya. Busran dan Yunanda juga telah membangun aplikasi iqro' untuk anak usia dini[12]. Aplikasi dilengkapi dengan gambar-gambar yang menarik, sehingga diharapkan siswa dapat dengan mudah mempelajari materi dengan efektif, efisien dan lebih menyenangkan. Penelitian Fatoni dkk telah mengembangkan media pembelajaran Al-Qur'an berbasis android[13]. Aplikasi ini dikembangkan dengan tujuan untuk mempermudah guru dalam mengajar atau menyampaikan materi dan juga memudahkan siswa untuk belajar dimana saja dan kapan saja, karena aplikasi ini dapat diinstal di Smartphone yang orang tua atau siswa miliki.

Rokhim dan Fuad telah membuat aplikasi pengenalan huruf alphabet untuk anak usia balita menggunakan android based mobile[14]. Aplikasi ini sudah menggunakan gambar dan suara untuk menarik minat anak belajar alphabet. Seperti yang disampaikan oleh Amrulloh dan Mulyoto pada penelitiannya bahwa aplikasi yang dilengkapi dengan unsur animasi dalam media pembelajaran interaktif dapat membuat siswa tidak cepat bosan dan lebih cepat menghafal[15]. Tidak kalah dari itu menumbuhkan suasana belajar merupakan salah satu faktor pendukung yang tidak bisa diabaikan begitu saja. Menumbuhkan suasana belajar yang bisa diterima di situasi apapun, dimanapun dan kapanpun. Salah satunya dengan menciptakan media pembelajaran berbasis android yang interaktif yang dapat membuat anak belajar dimana saja dan kapan saja[16].

\section{Metode Penelitian}

Pada penelitian ini terdapat beberapa tahapan yang dilakukan diantaranya adalah mulai dari tahap identifikasi masalah, menentukan solusi permasalahan, membuat dokumen perancangan, membuat prototype dan menguji coba prototype. Tahap-tahap ini dapat dilihat pada kerangka pemikiran penelitian yang tergambar pada Gambar 1 .

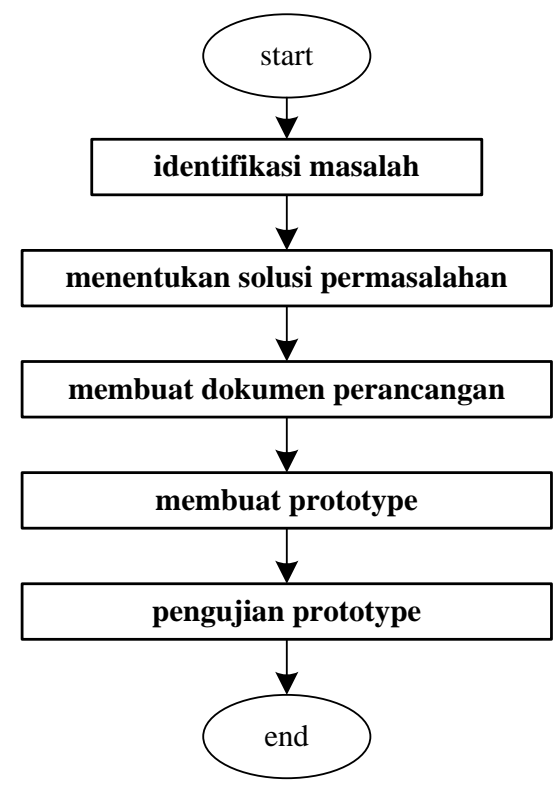

Gambar 1. Alur Penelitian

2.1. Identifikasi Masalah

- memanfaatkan smart phone tidak hanya untuk bermain game, tetapi untuk belajar

- menarik minat anak untuk mengenal huruf abjad

\subsection{Menentukan solusi permasalahan}

Membuat aplikasi belajar membaca yaitu aplikasi untuk belajar membaca disertai gambar animasi berbasis android

\subsection{Membuat dokumen perancangan}

Pada tahap ini akan dibuat Use case diagram, sequence diagram, dan juga perancangan interface dari aplikasi belajar membaca berbasis android.

\subsection{Membuat prototype}

Pada tahapan ini memulai untuk menterjemahkan dokumen perancangan ke dalam baris program

\subsection{Pengujian prototype}

Pengujian menggunakan metode black box testing [17], yaitu dengan melakukan uji coba terhadap menu-menu yang ada dalam aplikasi membaca berbasis android, apakah sudah berjalan sesuai dengan apa yang sudah dibuat di dokumen perancangan. 


\section{Hasil dan Pembahasan}

Dokumen perancangan yang baik dan benar sehingga dapat diimplementasikan dengan mudah dalam membangun system yang sesuai dengan apa yang diinginkan. Use case diagram aplikasi belajar membaca berbasis android dapat dilihat pada Gambar 2.

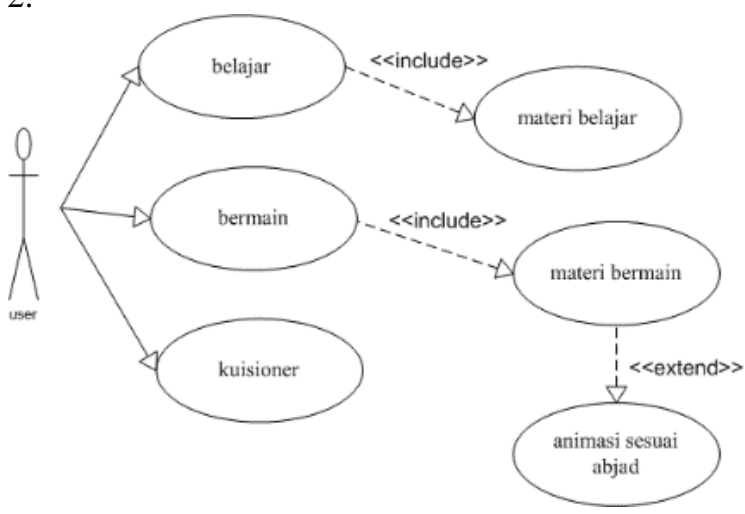

Gambar 2. Use Case Diagram Aplikasi

Pada aplikasi belajar membaca berbasis android ini terdapat 3 menu utama yaitu, menu belajar, menu bermain dan juga menu form. Menu Form berisi kuisioner tentang aplikasi belajar membaca berbasis android, dimana hal ini berguna untuk bahan evaluasi tim developer dalam mengembangkan aplikasi belajar membaca ini.

Di dalam menu belajar anak akan diperkenalkan dengan abjad mulai dari A - Z. Abjad-abjad ini akan menampilkan gambar animasi beserta ejaannya ketika di klik. Pada menu bermain, anak akan diberikan soal berupa sambung kata disertai gambar animasi. Caramenjawabnya adalah anak akan diberikan tampilan abjad yang sudah diacak, dan anak akan memilih jawaban sesuai dengan ejaannya. Sequence diagram aplikasi belajar membaca berbasis android dapat dilihat pada Gambar 3 dan Gambar 4.

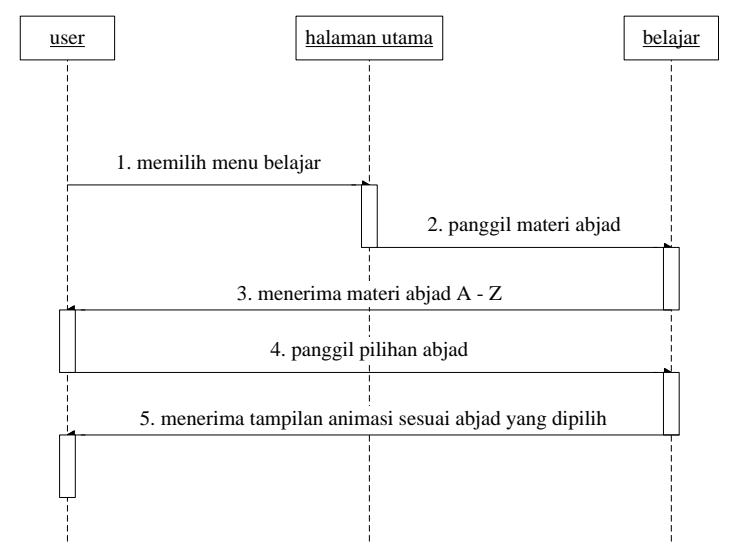

Gambar 3. Sequence Diagram Menu Belajar

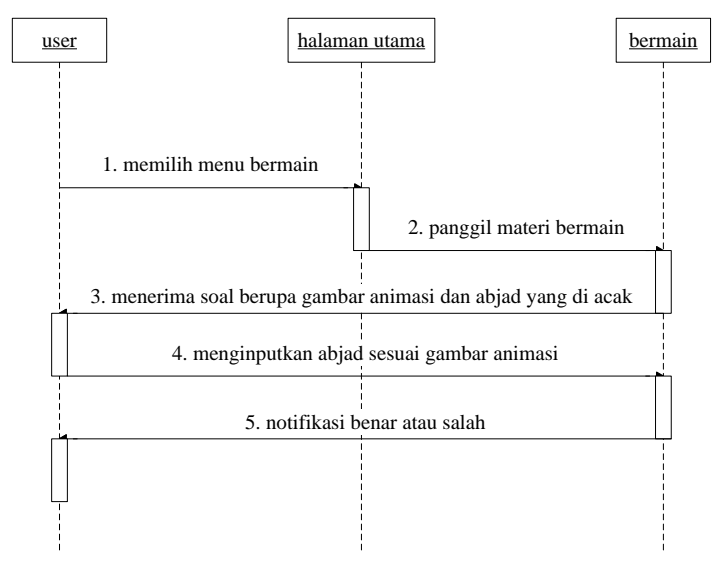

Gambar 4. Sequence Diagram Menu Bermain

Dalam membuat prototype aplikasi belajar membaca berbasis android ini juga membuat perancangan interface di tahap perancangannya. Perancangan interface aplikasi belajar membaca berbasis android dapat dilihat pada gambar 5 Gambar 8.

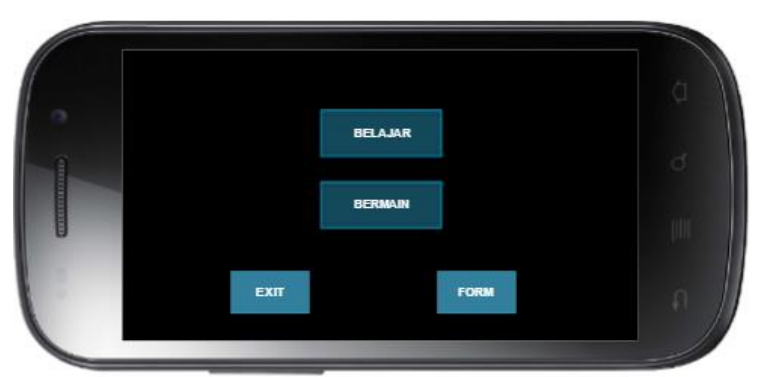

Gambar 5. Tampilan Utama Aplikasi

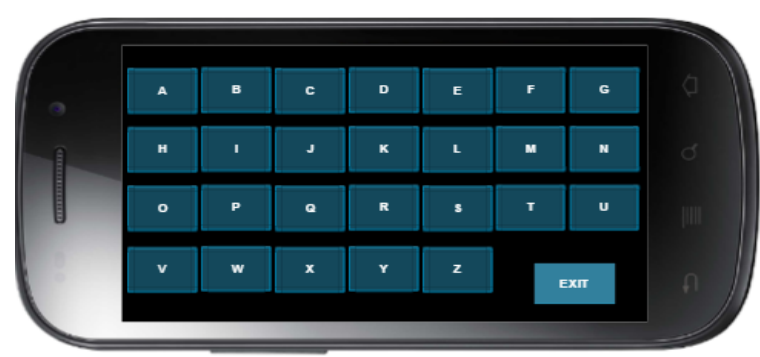

Gambar 6. Tampilan Menu Belajar

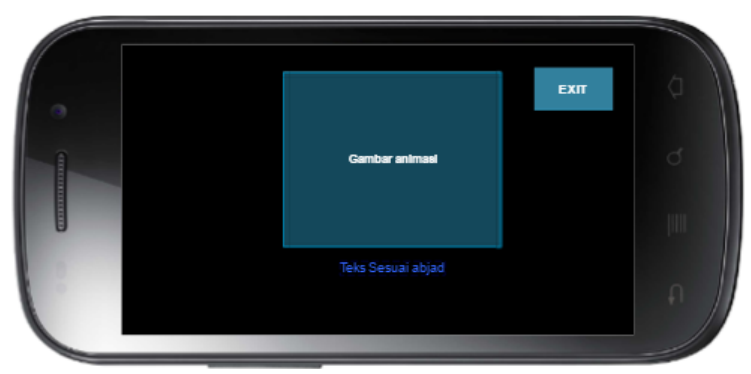

Gambar 7. Tampilan Gambar Animasi sesuai Abjad 


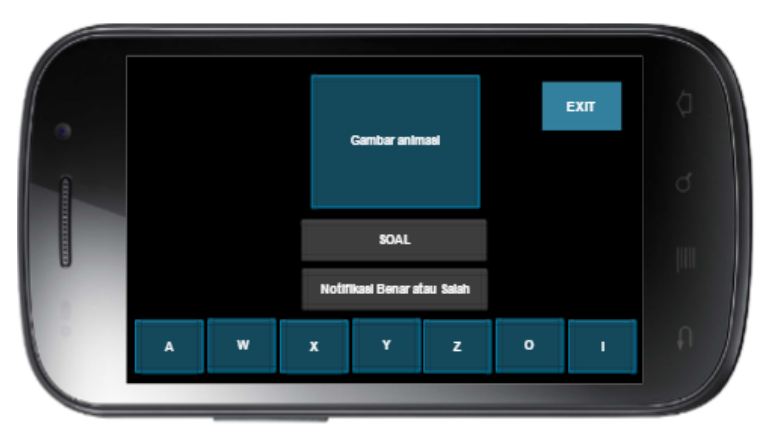

Gambar 8. Tampilan Menu Bermain

Pengujian aplikasi ini menggunakan metode black box testing, yaitu untuk mengetahui apakah menumenu yang terdapat dalam aplikasi sudah berjalan sesuai dengan apa yang sudah dirancang di dokumen perancangan. Hasil pengujian terhadap menu-menu yang ada dalam aplikasi belajar membaca ini dapat dilihat pada Tabel 1.

Tabel 1. Pengujian Aplikasi

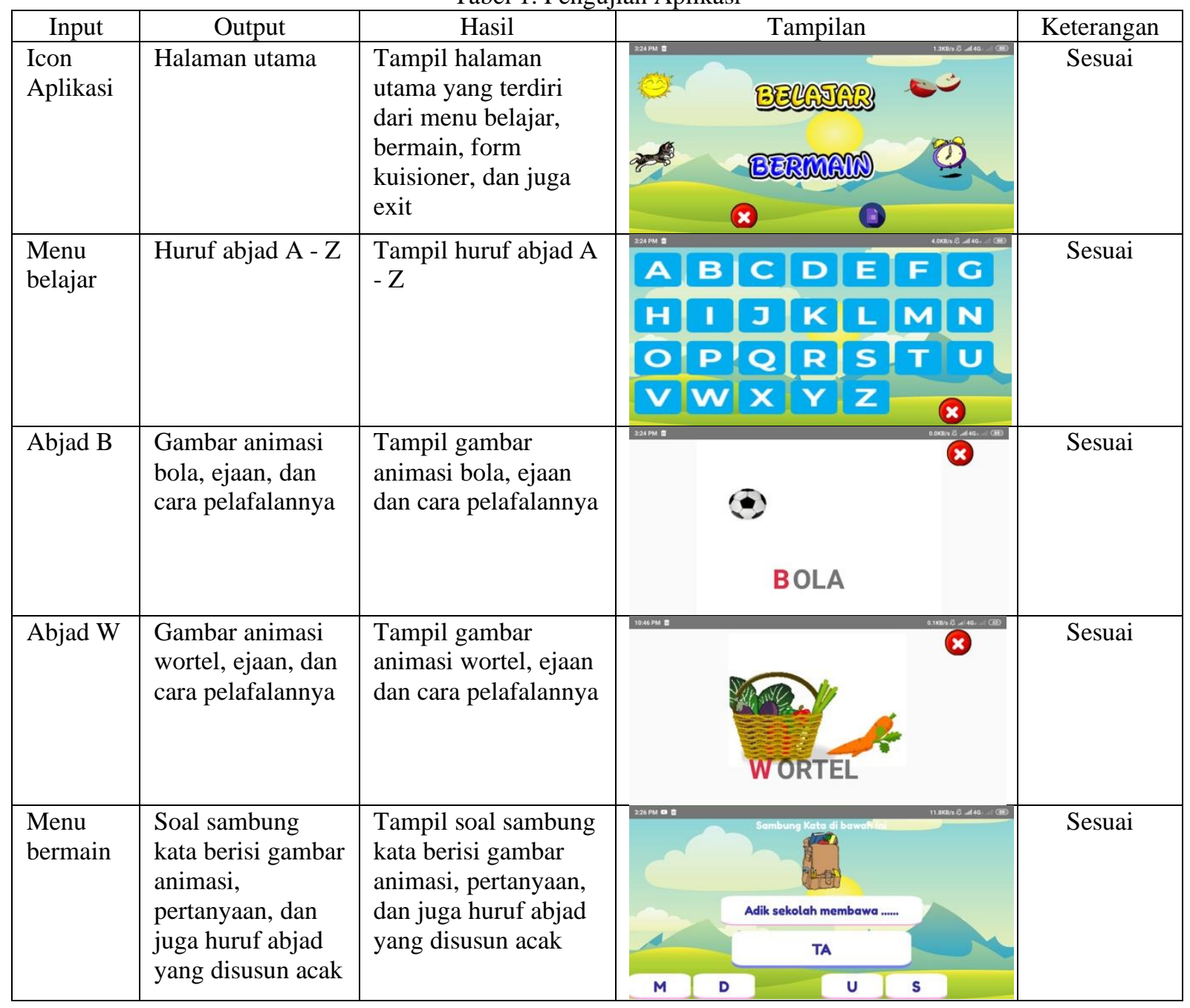

\section{Kesimpulan dan Saran}

Aplikasi yang telah dibangun ini adalah aplikasi belajar membaca atau mengenal abjad yang berbasis android dengan gambar animasi. Aplikasi diujikan ke anak-anak pra sekolah atau taman kanakkanak dengan panduan Guru atau dibimbing orang tua langsung. Menurut mereka aplikasi sudah baik, sarannya adalah perlu ditambah kosa-kata Bahasa Indonesianya. Harapan dari dibangunnya aplikasi ini adalah menarik minat user atau penggunanta yaitu anak usia pra sekolah atau taman kanak-kanak untuk mengenal abjad dengan tampilan aplikasi berupa gambar animasi yang menarik. Aplikasi ini dilengkapi dengan menu bermain untuk melatih kemampuan anak dalam menyambung kata dan mengeja huruf abjad. Hasil pengujian dengan metode black box pada aplikasi yang dibuat menunjukkan bahwa menu-menu berjalan dengan baik sesuai apa yang diharapkan di dokumen perancangan. Pengembangan aplikasi lebih lanjut dengan dilengkapi gambar berbasis augmented reality.

\section{Daftar Pustaka:}

"Kementerian Komunikasi dan Informatika." https://kominfo.go.id/content/detail/6095/indones ia-raksasa-teknologi-digital-asia/0/sorotan_media 
(accessed Jul. 06, 2020).

R. Chadha, "Smartphones Move Upmarket in Indonesia," 2017. https://www.emarketer.com/Article/Smartphones -Move-Upmarket-Indonesia/1016459 (accessed Jul. 06, 2020).

S. Implikasinya, A. Sosial, and B. Masyarakat, "Survey Penggunaan T I K 2001 7," 2017. Accessed: Jul. 06, 2020. [Online]. Available: www.kominfo.go.id.

"Badan Pusat Statistik." https://www.bps.go.id/publication/2019/12/02/67 99f23db22e9bdcf52c8e03/statistik-

telekomunikasi-indonesia-2018.html (accessed Jul. 06, 2020).

E. Wulandari, G. A. Buntoro, and A. Y. Astuti, "Rancang Bangun Game Edukasi Pembelajaran Anak Usia Dini pada RA Miftahul Fatah Sayutan Berbasis Android," KOMPUTEK, vol. 4, no. 2, p. 95, Oct. 2020, doi: 10.24269/jkt.v4i2.538.

S. - and M. H. Qamaruzzaman, "Rancang Bangun Visualisasi Pembelajaran Berbasis Android Untuk Anak," Sistemasi, vol. 8, no. 3, p. 386, 2019, doi: 10.32520/stmsi.v8i3.518.

"Survey tentang Smartphone \& Tablet - Hasilnya Mengejutkan | theAsianparent Indonesia." https://id.theasianparent.com/hasil-surveysmartphone-yang-mengejutkan (accessed Jul. 06, 2020).

M. Zaini and S. Soenarto, "Persepsi Orangtua Terhadap Hadirnya Era Teknologi Digital di Kalangan Anak Usia Dini," J. Obs. J. Pendidik. Anak Usia Dini, vol. 3, no. 1, p. 254, 2019, doi: 10.31004/obsesi.v3i1.127.

H. Heni and A. J. Mujahid, "Pengaruh Penggunaan Smartphone terhadap Perkembangan Personal Sosial Anak Usia Pra-Sekolah," J. Keperawatan Silampari, vol. 2, no. 1, pp. 330-342, 2018, doi: 10.31539/jks.v2i1.341.

T. H. E. Intensity, O. F. Gadgets, U. S. E. By, and P. Children, "Intensitas Penggunaan Gadget pada Anak usia Pra,” pp. 488-499, 2019.

Kurnia Muludi, D. Kurniawan, and A. Habibullaah, "Rancang Bangun Aplikasi Pembelajaran Iqra Berbasis Android," J. Momentum, vol. 17, no. 1, pp. 1-9, 2015.

N. D. Yunanda et al., "Rancang Bangun Aplikasi Pembelajaran Iqra Untuk Anak Usia Dini Berbas. Android," vol. 17, no. 1, 2015.

K. Fathoni, A. B. Utomo, A. Hangga, and O. P. Pamungkas, "Pengembangan Media Pembelajaran Al-Qur' an Berbasis Android di $T P Q$ Al-," Edu Komputika J., vol. 5, no. 2, pp. 110-116, 2019, [Online]. Available: http://journal.unnes.ac.id/sju/index.php/edukom.

A. Rokhim, N. Fuad, S. Yadika, and U. I. Lamongan, "Pembuatan Aplikasi Pengenalan Huruf Alfabet Untuk Anak Balita Pada Sistem Operasi Android," vol. 7, no. 2, pp. 48-52, 2015.

H. Fatah, N. Ichsan, T. Wahyuni, E. Ernawati, and I.
Indriyanti, "Rancang Bangun Program Aplikasi Pembelajaran Aksara Sunda Berbasis Android," Sistemasi, vol. 9, no. 2, p. 304, 2020, doi: 10.32520/stmsi.v9i2.770.

I. P. Astuti, D. Ariyadi, and L. Sumaryanti, "Prototipe Media Pembelajaran Berbasis Android Untuk Membaca Permulaan," Simetris J. Tek. Mesin, Elektro dan Ilmu Komput., vol. 11, no. 1, pp. 151156, 2020, doi: 10.24176/simet.v11i1.3791.

L. Affandi, Ekojono, and Rudy Ariyanto, "Sistem Penjadwalan Sidang Tugas Akhir Menggunakan Metode Analytical Hierarchy Pprocess Di Jurusan Teknologi Informasi Politeknik Negeri Malang”, JIP, vol. 6, no. 4, pp. 31-36, Aug. 2020. 
Volume 7, Edisi 3, Mei 2021

$34 \mid \mathrm{H}$ a 1 a $\mathrm{m}$ a $\mathrm{n}$ 